\title{
A sistematização legislativa do assédio moral no trabalho no âmbito das administrações públicas estaduais no Brasil
}

\author{
The legislative systematization of workplace bullying in the scope of the state \\ public administrations in Brazil
}

\author{
Rafael Maia Nogueira ${ }^{1}$ \\ Thiago Soares Nunes ${ }^{2}$ \\ Antônio Carvalho Neto ${ }^{3}$ \\ Raphael Rodrigues Ferreira ${ }^{4}$
}

\begin{abstract}
Resumo
O assédio moral no trabalho é compreendido, principalmente, como uma modalidade de agressão psicológica que se apresenta por meio de repetida exposição do indivíduo a situações humilhantes no ambiente de trabalho. Dada a importância da temática, as assembleias legislativas estaduais editaram normas para prevenir e punir essa prática no âmbito de suas administrações. Nesse sentido, este artigo objetiva descrever como as legislações estaduais brasileiras se referem ao assédio moral no trabalho, no que diz respeito a sua caracterização, punição, prevenção e proteção ao alvo. Quanto ao método, a pesquisa foi subsidiada pela investigação jurídico-comparativa das normas que abordam sobre o assédio moral no âmbito das administrações públicas estaduais, classificando-se como uma análise documental. Constatou-se um crescimento de legislações nos últimos anos, todavia ainda não embarcando todos os estados brasileiros. Além disso, as legislações abrangeram descrições sobre algumas estratégias de assédio moral no seu conteúdo, principalmente as mais difíceis de serem identificadas. Quanto ao sistema de denúncia, apuração e punição, apenas um estado apresenta uma Comissão de prevenção e combate, o que demonstra ser uma situação que denota preocupação. Por fim, é evidente que as legislações ainda são incipientes se comparadas à complexidade da temática, dessa forma, muito ainda precisa ser feito para que possa garantir a redução e erradicação da violência no ambiente laboral.
\end{abstract}

Palavras-chave: Assédio moral no trabalho; Administração Pública; Legislação.

\begin{abstract}
Workplace bullying is understood mainly as a form of psychological aggression that occurs through repeated exposure of the individual to humiliating situations in the work. Given the importance of the topic, the state parliament have edited legislation to prevent and punish this practice within their administrations. In this sense, this article aims to describe how Brazilian state legislations refer to workplace bullying, as regards their characterization, punishment, prevention and protection of the victim. As for the method, the research was subsidized by the legal-comparative investigation of the norms that deal with workplace bullying in the scope of the State Public Administrations, classified as a documentary research. There has been a growth of legislation in recent years, although not yet embarking all the Brazilian states. In addition, the legislation covered descriptions of some bullying strategies in their content, especially the most difficult to identify. As for the system of denunciation, investigation and punishment, only one state presents a commission of prevention and combat, which shows that it is a situation that denotes concern. Finally, it is clear that legislation is still incipient when compared to the complexity of the issue, so much still needs to be done to ensure the reduction and eradication of violence in the workplace.
\end{abstract}

Keywords: Workplace bullying; Public Administration; Law.

Mestre em Administração pela Pontifícia Universidade Católica de Minas Gerais - PUC Minas. Afiliação: Pontifícia Universidade Católica de Minas Gerais. Brasil. Lattes: http://lattes.cnpq.br/3101256620871998 Email: rafaelmaianogueira@gmail.com

2 Pós-Doutorado em Administração pela Universidade Estadual de Maringá (2018). Doutor em Administração pela Universidade Federal de Santa Catarina (2016), com período sanduíche no Departamento de Psicologia Social da Universidade Autônoma de Barcelona (UAB/Espanha) (2015). Afiliação: Centro Universitário UNA. Brasil. Lattes: http://lattes.cnpq.br/3796147728637598 Orcid: http://orcid.org/0000-0002-1323-8160 Email: adm.thiagosn@gmail.com

3 Doutor em Administração. Professor no Programa de Pós-Graduação em Administração da Pontifícia Universidade Católica de Minas Gerais - PUC Minas. Afiliação: Pontifícia Universidade Católica de Minas Gerais. Brasil. Lattes: http://lattes.cnpq.br/2169195614253730 Email: carvalhoneto@pucminas.br

4 Mestrando em Direito Político pelo Programa de Pós-Graduação da Faculdade de Direito da Universidade Federal de Minas Gerais. Afiliação: Universidade Federal de Minas Gerais. Brasil. Lattes: http://lattes.cnpq.br/4510970464892247 Email: raphael.ferreira@outlook.com.br 


\section{Introdução}

O assédio no trabalho consiste em uma modalidade de agressão psicológica que se apresenta por meio de repetida exposição do indivíduo a situações humilhantes e de desqualificação no ambiente de trabalho, de forma a atacar tanto sua integridade profissional quanto pessoal (Freitas, 2001; Heloani, 2004; Vasconcelos, 2015), podendo ter pode ter diversas origens quanto à posição hierárquica dos agressores em relação ao agredido (Nunes \& Tolfo, 2015).

Seus impactos se estendem ao âmbito individual, provocando desordens diversas na vida do assediado; ao âmbito organizacional, com queda na produtividade, custas judiciais, dentre outros prejuízos; e ao âmbito social, com aumento dos custos em saúde e previdência, aumento de suicídios, desestruturações familiares, perda de investimentos e de produtividade do indivíduo assediado (Keashly \& Jagatic, 2003; Freitas, 2007). Por essas razões, é imprescindível compreender cada vez mais a sua ocorrência, de forma capacitar as organizações a atuar positivamente nas atividades de apurar, coibir e punir os responsáveis, sem exceções.

Deve-se, portanto, ir além de medidas corretivas que objetivam a resolver determinada situação, construindo estratégias que possibilitem uma maior proteção e amparo, principalmente para o indivíduo que é alvo deste e de tantas outras violências no âmbito laboral. As políticas e legislações, por exemplo, podem ser elementos que possibilitam maior segurança para o trabalhador, o qual, em situações de assédio moral, fica desemparado sem saber a quem pedir ajuda e socorro.

Embora ações como estas e tantas outras sejam importantes para prevenir e combater a violência, ou até mesma a fazer conhecida, o fato é que as organizações raramente desenvolvem medidas em prol do trabalhador assediado ou sobre a temática (Nunes, 2016), fato este observado nas mais diversas pesquisas que relatam sobre o assédio sofrido pelos trabalhadores. Portanto, cabe também ao próprio Estado e aos mais diversos órgãos agirem em prol da saúde e proteção do trabalhador, mediante a construção de leis, fiscalizações e multas.

Nesse sentido, a pergunta que esse trabalho pretende responder é: como os estados da federação brasileira estão legislando sobre o assédio moral no âmbito de suas administrações públicas? Para tanto, foi estabelecido o objetivo geral de descrever como as legislações estaduais brasileiras se referem ao assédio moral no trabalho, no que diz respeito a sua caracterização, punição, prevenção e proteção à vítima. Como objetivos específicos, buscou-se: levantar quais estados possuem legislação específica sobre assédio moral; verificar a aderência das normas à literatura quanto à classificação de assédio; levantar em quais legislações estaduais há previsão de sistema específico de denúncia, apuração e punição dessa prática; e em quais estados é previsto sistema de prevenção e apoio às vítimas de assédio moral.

O trabalho ora apresentado revela-se como uma importante contribuição ao campo de estudos da Administração, em especial da Administração Pública, uma vez que possibilita compreender como esse tema é compreendido pela classe política, o amparo legal que dá suporte à atuação das unidades de recursos humanos e de controle e quais práticas políticas estão sendo implementadas, com possibilidades de verificação de novas práticas desempenhadas pelos estados.

A compreensão da sistematização das normas estaduais afetas à matéria, tal como se propõe, irá revelar a forma como os estados estão buscando - no âmbito normativo - lidar com as práticas de assédio. De tal sorte, este estudo poderá vir a servir como um subsídio para gestores públicos aprimorem suas políticas de prevenção e coibição.

\section{Assédio moral no trabalho}

Embora o assédio moral seja considerado como um tema novo nas pesquisas acadêmicas e no próprio debate no meio laboral e social, foi a partir dos anos 90 que se torna objeto de estudo e interesse na área da Administração. Fato este devido aos efeitos destrutivos que podem ser proporcionados no ambiente laboral (Freitas, 2001), que vão além de aspectos individuais (saúde) e relacionais (clima de trabalho e relacionamentos), e repercutem na própria organização (desempenho, imagem, produtividade) (Keashly \& Jagatic, 2003; Nunes \& Tolfo, 2012). 
Os conceitos de assédio moral apresentados pelos autores e pesquisadores nacionais e internacionais, são, em sua maioria, similares e complementares (Nunes, Tolfo, \& Espinosa, 2018). Destacamos, a seguir, algumas definições da temática:

Assédio moral no trabalho é definido como qualquer conduta abusiva (gesto, palavra, comportamento, atitude...) que atente, por sua repetição ou sistematização, contra a dignidade a integridade psíquica ou física de uma pessoa, ameaçando seu emprego ou degradando o clima de trabalho (Hirigoyen, 2006, p. 17).

Assédio moral no trabalho pode ser definido como ações e práticas repetidas, dirigidas a um ou mais trabalhadores de forma deliberada ou inconsciente, que são indesejados pela vítima, e causam humilhação, ofensa e angústia, além de poder interferir no desempenho do trabalho e/ou causar desagradável ambiente de trabalho (Einarsen, Hoel, Zapf, \& Cooper, 2005, p. 230 - tradução nossa).

Assédio moral é uma conduta abusiva, intencional, frequente e repetida, que ocorre no meio ambiente laboral, cuja causalidade se relaciona com as formas de organizar o trabalho e a cultura organizacional, que visa humilhar e desqualificar um indivíduo ou um grupo, degradando as suas condições de trabalho, atingindo a sua dignidade e colocando em risco a sua integridade pessoal e profissional (Heloani \& Barreto, 2018, p. 53).

Por ter se tornado um tema "popular" na academia a na mídia, a compreensão e caracterização do assédio muitas vezes é feita de forma errônea (Nunes et al., 2018). Desse modo, sua caracterização denota certa atenção. Existe um conjunto de características que auxiliam na definição do assédio, a saber: a intencionalidade, cuja forma pode ser deliberada ou não, sendo que a não intencional não torna o ato menos violento ou danoso à vítima; a direcionalidade do ato, a um indivíduo um grupo específico; a frequência e duração, de modo que o assédio moral é uma situação frequente e repetitiva, e não um ato isolado; o desequilíbrio de poder, situações em que a capacidade de ataque e defesa de cada um é desigual, não se remetendo necessariamente ao poder hierárquico; e o caráter processo, haja vista que o assédio moral pode "evoluir" gradativamente, passando de situações mais veladas para ataques mais visíveis e violentos (Einarsen, Hoel, Zapf, \& Cooper, 2011; Nunes et al., 2018).

Dentre as diversas estratégias hostis que são utilizadas pelos agressores, apresentamos, neste artigo, a classificação que a autora francesa Marie-France Hirigoyen (2006), considerada a pesquisadora que popularizou o tema mundialmente, desenvolveu. A autora agrupa as situações hostis em quatro categorias, de mais sútil (difícil de ser identificada) até a mais visível, são elas: deterioração proposital das condições de trabalho, em que são praticados atos para que o alvo pareça ser incompetente, em geral proveniente de superiores; isolamento e recusa de comunicação, em que ocorrem ações de recusa da comunicação e de exclusão dos eventos sociais, ocorrendo tanto por superiores quanto por pares; atentado contra a dignidade, em que são desferidos atos de desprezo, de desqualificação ou chacotas, geralmente desferidas por pares; e violência verbal, física ou sexual, em que os atos de violência se apresentam como ameaças, violência física e assédio sexual, podendo extrapolar o ambiente de trabalho.

Na pesquisa de Nunes (2016) com servidores universitários (docentes e técnicosadministrativos), o autor encontrou como situações recorrentes: ser exposto a uma carga excessiva de trabalho; realizar atividades abaixo do nível de competência; e ter opinião e pontos de vistas ignorados. Portanto, principalmente situações de deterioração proposital das condições de trabalho e isolamento e recusa de comunicação. Ademais, os motivos identificados pelas vítimas para "justificar" o assédio foi o posicionamento do alvo (seja político, ideológico ou em relação ao trabalho), a categoria a qual pertence (docente ou técnico), o tempo de instituição (se está ou não em estágio probatório) e o pertencimento ou não ao grupo dominante. Embora a pesquisa tenha sido em um setor em específico, os seus resultados podem ser encontrados em muitas organizações públicas e privadas. A forma em que se manifesta a violência, ou seja, quem a pratica, também pode ser diferente a depender da categoria/formação. Entre docentes, o mais comum é que o assédio seja perpetrado pelos próprios pares (outros docentes) por motivos diversos (inveja, disputas de poder, entre outros), já entre os técnicos o assédio parte comumente do superior hierárquico (abuso de poder). 
No serviço público, o assédio moral pode durar anos, um dos fatores é a estabilidade, tanto da vítima quanto do agressor (Hirigoyen, 2006). Sendo o emprego o único meio para a sobrevivência do alvo e de sua família, ele tende a aguentar a violência, intensificando seus efeitos para a sua saúde (Hirigoyen, 2006; Nunes, 2016). Por sua vez, a estabilidade do agressor compreende que ele não será punido, por exemplo, com uma demissão tão facilmente, ainda mais devido à sutileza com que muitas das estratégias hostis são perpetradas. Chapadeiro (2015) comenta que, embora o assédio moral não esteja expressamente presente em legislações, como a CLT, ele é considerado pela jurisprudência como uma falta grave, que pode justificar a perda da estabilidade e justa causa para rescisão do contrato de trabalho.

O elemento da estabilidade não significa que o assédio moral no setor público é mais perverso do que no setor privado, mas pode ser mais nocivo ao longo do tempo, pois muitas vezes as vítimas estão "presas" no setor, e não conseguem pedir uma transferência de setor (estratégia utilizada por muitos) (Nunes \& Tolfo, 2013; Zanin, Künzle, Barreto, \& Heloani, 2015). O caso se intensifica quando o agressor é o próprio superior hierárquico, que tem determinado poder investido no cargo, podendo, assim, atrapalhar e extinguir qualquer ação do alvo para com ele ou pedido de socorro para outras instâncias (Hirigoyen, 2006; Nunes \& Tolfo, 2013). Em caso apresentado por Nunes (2016) em uma universidade pública brasileira, quando um servidor foi realizar uma denúncia sobre as práticas hostis perpetradas contra ele, o agressor tomou conhecimento da denúncia, intensificouas e utilizou de seu poder para criar dificuldades para a vítima, como a mudança de setor (uma forma de acabar com as agressões).

O fato é que o assédio moral é uma situação que existe desde sempre, se manifestando de diferentes maneiras conforme o contexto em que ocorre (Heloani, 2004; Nunes et al., 2018). O acirramento da competitividade pode ter um efeito de potencializar o assédio moral, de modo que "a administração por stress permite a naturalização de caminhos reprováveis, que servem de via de acesso para dar vazão à falta de escrúpulos de profissionais perversos, que retiram prazer de atos aviltantes e tirânicos" (Freitas, 2001, p. 18). Outros pesquisadores salientam que os sistemas de poder e as estruturas dos processos existentes nas organizações, transcendentes ao âmbito individual ou interpessoal, também constituem aspecto crucial na amplificação dos abusos (Harrington, Warren, \& Rayner, 2015). Não esquecendo que a proteção e o aumento da autoestima, a falta de competências sociais e de controle emocional e a vaidade podem levar ao indivíduo a ter comportamentos agressivos (Zapf \& Einarsen, 2003).

No serviço público o assédio moral está associado, principalmente, aos abusos e disputas de poder (Hirigoyen, 2006; Heloani \& Barreto, 2018). Podendo, segundo os autores, ser motivado por aspectos grupais, ou seja, dependendo de que grupo dominante, partido político ou quem você conhece, terá certos benefícios; caso não, algumas sanções e revezes poderão ocorrer (Nunes, 2016). Nesse aspecto, é um traço presente na cultura brasileira e na cultura do serviço público, o paternalismo, que apresenta relações onde o pertencimento a determinado grupo pode abrir caminhos e recompensas (Prates \& Barros, 1997; Carbone, 2000).

Outro aspecto levantado por Martiningo Filho e Siqueira (2008 - grifo nosso) sobre o que favorece o assédio, são os ambientes em que não existem regras internas formais ou informais (de comportamento, método etc.), que promovem que "tudo seja permitido" e, assim, o poder dos superiores se torna "ilimitado"; além daqueles trabalhadores que não se adaptam à lógica do grupo.

Não obstante, não devemos pensar o assédio moral como uma situação interpessoal (relação entre alvo e agressor), pois ele é um fenômeno social complexo, que envolve aspectos psicológicos, interpessoais, organizacionais e sociais (Nunes \& Tolfo, 2015). Por ocorrer no ambiente laboral, a própria organização se torna corresponsável pela sua ocorrência, seja por não estipular limites em regras ou instâncias de punição, seja por aceitarem a sua prática, uma vez que, com isso, conseguem alcançar e ultrapassar as suas metas e sua produtividade (Freitas, 2007; Nunes, 2016). A própria organização também é influenciada e influencia o contexto no qual ela interage, assim, ressaltamos que a própria sociedade e a cultura local/ nacional, mediante seus valores e normas, influenciam na ocorrência do assédio moral (Nunes, 2016). 0 autor identificou, em uma universidade federal, elementos que podem influenciar a ocorrência de assédio moral e outras violências, as quais também estão presentes no serviço público de forma geral, a saber: impunidade; questões grupais (categoria a qual pertence, se novo ou antigo, se efetivo ou temporário); grupos 
dominantes ou de poder; aspectos políticos (partidários ou não); despreparo em exercer a atividade (é posto no cargo sem ter preparo e/ou saber gerir pessoas); ambiguidades (existência de uma cultura tradicionalista, de fazer "as coisas como sempre foram feitas" ao invés de seguir as normas e regras estipuladas); e uma disparidade entre o discurso e a prática.

Os conflitos existentes na sociedade em geral podem acarretar comportamentos hostis, violentos, manifestando-se como ridicularizações, destratamentos e isolamentos (Soylu \& Sheehy-Skeffington, 2015). Nesse sentido, pessoas pertencentes a grupos historicamente discriminados, como é o caso das mulheres, dos negros, das pessoas com deficiência e dos homossexuais, estariam mais suscetíveis a sofrer violência. Praticamente todo assédio é discriminatório, uma vez que ocorre mediante a recusa de características e particularidades de uma pessoa (Hirigoyen, 2006).

O assédio moral provoca impactos: no âmbito individual, provocando desordens na vida psíquica, social, profissional, familiar e afetiva do assediado; no âmbito organizacional, com ampliação de afastamentos por doenças e acidentes de trabalho, absenteísmos, turnover, queda na produtividade, custas judiciais, bem como impactos em sua imagem; e no âmbito social, com aumento dos custos em saúde e previdência, aumento de suicídios, desestruturações familiares, perda de investimentos e também de produtividade do indivíduo assediado (Hoel, Sparks, \& Cooper, 2001; Keashly \& Jagatic, 2003; Nunes \& Tolfo, 2012). Ele pode gerar vários sintomas físicos, como fadiga e distúrbio do sono, sintomas psíquicos, como dificuldades de concentração e lapsos de memória, e sintomas comportamentais, como irritabilidade e perda de interesse pelo trabalho (Barreto, 2006; Vasconcelos, 2015).

Observa-se, portanto, que o assédio moral não pode ser ignorado pela organização e gestores, pois seus efeitos são devastadores, principalmente para o indivíduo vítima dessa situação. O que se constata, porém, é a falta de ações dos gestores da organização e, principalmente, da área de gestão de pessoas, que deveria trabalhar na prevenção, combate e orientação do assédio e tantas outras temáticas importantes (Nunes, 2016). Segundo Martiningo Filho e Siqueira (2018), para a manutenção de um ambiente saudável, é de grande importância observar a forma como a organização, em especial a área de gestão de pessoas, administra os conflitos internos, pois se constata que grande parte se mostra inábil para gerir situações adversas.

Para Guimarães e Emmendoerfer (2015), a área de gestão de pessoas tem como atividade a execução e avaliação das atividades administrativas, e das políticas de gestão e desenvolvimento de pessoas, contribuindo para o alcance dos objetivos organizacionais. Para os autores, em sua pesquisa no setor público, funcionários da área de gestão de pessoas informaram que os trabalhadores assediados procuram pouco o setor para relatar os casos (que são muitos) e, quando o fazem, comentam que os orientam, prestando suporte e encaminhamentos, inclusa a orientação psicológica e de assistentes sociais. Portanto, na pesquisa dos autores ficou evidente a boa atuação da área de gestão de pessoas, em consonância com outros departamentos, para dar suporte à vítima, o que demonstra a consistência da gravidade que as situações de assédio moral podem proporcionar.

Para Martiningo Filho e Siqueira (2018), o desenvolvimento de políticas de prevenção, combate e monitoramento de casos de assédio moral não pode se restringir apenas à área de gestão de pessoas, deve ser uma preocupação de todos os gestores e funcionários. Ademais, para os autores, a área de gestão de pessoas precisa atentar-se, principalmente, para fatores situacionais no ambiente laboral, tal como pressões e avaliações de resultado baseados no volume de produção, sistema de recompensa injusto; organização deficiente do trabalho; disfunções na cultura e clima organizacional.

Ressalta-se que as práticas e políticas de gestão apresentam um papel fundamental na influência da ocorrência do assédio e, consequentemente, na sua coibição (Salin, 2008). Portanto, para intervir e combater a violência, as organizações devem reconhecer, primeiramente, que ela ocorre, e atuar positivamente em atividades de apuração, coibição e punição dos responsáveis, sem exceções (Freitas, 2007). Caso esses aspectos não ocorram, os efeitos na saúde e relacionamento dos trabalhadores, assim como no desempenho e na produtividade da organização, podem ser afetados (Freitas et al., 2008). Portanto, o empregador deve zelar por um trabalho saudável, sendo o assédio moral uma clara violação ao contrato de relação de trabalho. 
Além dos códigos de ética, podem-se criar mecanismos, por meio do departamento de Recursos Humanos da empresa, para dar ao trabalhador agredido o direito de denunciar a agressão de que tenha sido vítima, por escrito e sigilosamente; com esse fim, o indivíduo agredido pode utilizar caixas postais e mesmo "urnas" em dependências isoladas dentro da organização, para que, em tese, possa ter seu anonimato garantido. São passos para amenizar o problema, mas não bastam (Heloani, 2005, p. 105).

Ao analisar as denúncias de assédio moral de acordo com a perspectiva dos profissionais de recursos humanos, Harrington et al. (2015) detectaram dificuldades desse grupo em decidir entre a palavra do acusador e do acusado, bem como uma pressão da gestão por resolução rápida do conflito para minimizar danos à organização. Logo, segundo Einarsen e Hoel (2008), a equipe que deve analisar as situações de assédio precisa ter conhecimento do tema e ser formada por profissionais de diversas áreas de atuação (tais como psicólogos, administradores, advogados e outros), além de não terem relação com o acusado e o acusador. Martiningo Filho e Siqueira (2008, p. 28) corroboram que a área de gestão de pessoas "[...] precisa estimular a comunicação, baseada no desenvolvimento da autenticidade e da compreensão recíproca de situações profissionais complexas e, principalmente, nos casos de assédio, precisa providenciar interlocutores para escutar e analisar a situação das vítimas".

É importante que as medidas de prevenção, intervenção e combate de assédio moral sejam realmente aplicadas na organização, e não apenas discursos vazios dos gestores. Uma vez que, segundo Freitas et al. (2008) e Nunes e Tolfo (2013), a denúncia dos casos de assédio moral nas organizações não são recorrentes devido ao medo do acusador em realizar o ato e pela ineficiência organizacional para punir os agressores, uma vez que estes são protegidos, seja por pertencerem a grupos dominantes, seja por terem desempenho acima da média. Observamos, portanto, traços da cultura brasileira, como a impunidade e os "ismos" (corporativismo, personalismo, paternalismo) presentes na sociedade e nas organizações (Alcadipani \& Crubellate, 2003; Prates \& Barros, 1997).

Já pelo lado das organizações de defesa dos trabalhadores, Nogueira, Carvalho Neto e Nunes (2018) demonstram que são poucas as instituições sindicais que realmente se atentam para a questão do assédio. Todavia, segundo os autores, há experiências de ações concretas de sindicatos, atuando tanto na prevenção e combate quanto no apoio às vítimas de assédio.

Como o sistema interno da organização é ineficaz muitas vezes, os trabalhadores procuram a resolução da sua situação em ambientes externos à organização, ou seja, levam seus casos aos tribunais (Nunes \& Tolfo, 2013). A legislação brasileira não apresenta uma lei federal que trate exclusivamente sobre o assédio moral, contudo existem diversas leis que se relacionam com a violência.

\subsection{Legislação brasileira sobre o assédio moral}

A Constituição da República consagra, em seu art. $1^{\circ}$, inciso III, "a dignidade da pessoa humana" como um dos fundamentos da República Federativa do Brasil, destacando-se, ainda, nos termos do art. $5^{\circ}$, que são direitos fundamentais de todos os brasileiros e estrangeiros residentes no país: a inviolabilidade da intimidade, da vida privada, da honra e da imagem, assegurado o direito à indenização por danos materiais ou morais decorrentes de sua violação (Brasil, 1988).

A matéria, dada sua especificidade, é muito bem trabalhada no campo do Direito do Trabalho. A Consolidação das Leis Trabalhistas, por exemplo, estabelece hipóteses de rompimento unilateral de contrato de trabalho diante das ocorrências de falhas graves por uma das partes, sendo certo que, como o assédio moral se constitui numa falta grave por parte da empresa, o trabalhador pode pleitear a rescisão do contrato de trabalho. Todavia, conforme é possível extrair do art. 39 da Constituição, os servidores públicos estão submetidos a regime jurídico único, estabelecido por lei específica do respectivo ente federado, não se aplicando o disposto na CLT.

Noutro giro, analisando as normas decorrentes do art. 186 e seguintes do Código Civil Brasileiro, é possível extrair, do âmbito civil, a natureza ilícita da prática de assédio, decorrente de um ato comissivo ou omissivo, de negligência ou de imperícia, eis que seria ela responsável - tal como exposto no capítulo anterior - por causar danos ao assediado, ainda que exclusivamente morais. 
Todavia, a despeito da existência de normas proibitivas, é possível inferir, a partir da análise das legislações estaduais e da doutrina, que diversos são os desafios para a formulação de normas que sejam capazes de coibir a prática do assédio. Isto porque, além de tal prática estar circunstanciada por um elevado grau de subjetividade e dúvida (Harrington et al., 2015), a sua prova é de extrema dificuldade para a vítima, posto que, na maioria das vezes, o assediante "age às portas fechadas" (Dallegrave, 2013, p. 24)

Por essa razão, sugere-se que as medidas legislativas busquem compreender o maior número de hipóteses e impor medidas que possam coibir a conduta, bem como amparar as vítimas. Na ausência de previsão normativa que determine que certa conduta deva ser qualificada como "assédio moral", com vistas ao princípio da legalidade, caberá ao intérprete (gestor responsável por apurar os fatos), a partir das provas colhidas, fazê-lo amparado em normas mais genéricas. Nota-se, aqui, a ampliação do grau de subjetividade do julgador, contribuindo tanto para eventuais impunidades, nos casos em que se deixa de repelir práticas abusivas, quanto para condenações injustas em consequência da classificação de certas condutas como assédio moral de forma banalizada.

O legislador, por fim, pode e deve assumir um papel importante no processo de elaboração da norma. No âmbito da União, do Distrito Federal, dos estados e dos municípios, as legislações voltadas ao regime disciplinar dos servidores públicos são elaboradas a partir de projetos de lei de iniciativa do Poder Executivo. É o que determina, por exemplo, o artigo $61, \S 1^{\circ}$, inciso II, alínea "c" da Constituição da República, legislação replicada, de forma simétrica, pelos estados e pelos municípios nas Constituições Estaduais e nas Leis Orgânicas, e que determina que é de iniciativa privativa do Chefe do Poder Executivo as leis que dispõem sobre servidores públicos e seu regime jurídico. Dessa maneira, caberá ao gestor público compreender experiências - positivas e/ou negativas - de outras entidades para que Ihe sirvam como parâmetro para o aprimoramento daquelas vigentes em sua entidade.

\section{Método}

Trata-se pesquisa qualitativa, sendo o estudo de caráter descritivo, tendo em vista que pretende descrever o fenômeno da formação de legislações pelas Assembleias Legislativas estaduais acerca do assédio moral (Yin, 2005). A elaboração deste trabalho será subsidiada pela investigação jurídico-comparativa das normas que versam sobre a conduta de assédio no trabalho no âmbito das administrações públicas estaduais.

Segundo Gustin e Dias (2006), a investigação jurídico-comparativa presta-se à identificação de similitudes e diferenças de normas e instituições em dois ou mais sistemas jurídicos. Os resultados dessa comparação, segundo explicam, podem conduzir a transformações importantes, tanto na esfera teóricoargumentativa quanto no aumento da capacidade de decisão de alguma esfera prática.

O emprego desse modelo de investigação, portanto, tornou possível a identificação e a comparação das diferentes estratégias previstas no âmbito das administrações públicas estaduais brasileiras em relação ao assédio moral.

O método adotado para o presente estudo foi a análise documental, pois se trata da análise de documentos, quais sejam: as leis estaduais, que ainda não receberam tratamento analítico, tendo em vista os objetivos supramencionados (Gil, 2002). De acordo com Yin (2005), a análise de documentos tem como pontos fortes o fato de ser estável, exata e de ampla cobertura.

A estratégia de análise dos dados adotou a análise de conteúdo, que consiste em uma técnica de análise de textos objetivada para produção de inferências a partir da frequência da ocorrência de categorias delineadas (Bauer, 2003). Nesse sentido, foram elaboradas, para cada um dos objetivos, categorias de análise para produção de inferências. Para o objetivo de levantar se os estados possuem legislação específica sobre assédio moral, os estados foram divididos conforme os dispositivos encontrados nos sites das Assembleias Legislativas, sendo divididos em estados com legislação não encontrada, com dispositivo genérico em outras legislações e estados que possuem legislação específica, ordenados conforme evolução temporal.

Quanto à aderência dos tipos de assedio, foram levantados, nos estados que possuem legislação específica, elementos que possibilitassem a identificação das seguintes categorias: deterioração proposital das condições de trabalho; isolamento e recusa de comunicação; atentado contra a dignidade; violência 
verbal e física; assédio sexual; e previsão especial para pessoas de grupos historicamente discriminados (pessoas com deficiência, negros, gays, mulheres, entre outros). A referência teórica de análise foi a elaborada por Hirigoyen (2006), tendo sido dividida a violência verbal e física do assédio sexual, além de acrescida a violência contra grupos discriminados, conforme Soylu \& Sheehy-Skeffington (2015).

Por fim, quanto à previsão de sistema específico de denúncia, apuração e punição dessa prática, foi divididoem: meio especial para denúncia; e procedimento para apuração e sanções administrativas. Havendo ainda, por fim, sistema de prevenção e apoio às vítimas de assédio moral, dividido em: previsão de apoio às vítimas; e previsão de instrumentos de prevenção.

\section{Análise e interpretação dos resultados}

Tendo em vista o elevado número de normas a serem analisadas para responder o problema exposto, buscou-se, como recorte metodológico, avaliar, em um primeiro momento, as normas estaduais que visam coibir e punir a prática do assédio no âmbito das administrações públicas estaduais. Nesse sentido, não foram encontradas legislações específicas ou genéricas nos seguintes estados: Acre, Alagoas, Espírito Santo, Maranhão, Pará, Paraná, Piauí, Rio Grande do Norte, Santa Catarina e Sergipe.

Já nos estados da Bahia, Mato Grosso, Roraima e Tocantins, foram identificadas legislações genéricas, que tratam do tema em dispositivos genéricos, em legislações amplas, como no Mato Grosso, que na Lei Complementar 4, de 1990, define que será punível administrativamente servidor que "assediar sexualmente ou moralmente outro servidor público". Já no caso das legislações específicas, foram levantados os seguintes dispositivos, conforme Quadro 1.

Quadro 1 - Legislações estaduais

\begin{tabular}{|c|c|c|}
\hline ESTADO & LEGISLAÇÃO & ANO \\
\hline Amapá & Lei n. ${ }^{\circ} 1818$ & 2014 \\
\hline Amazonas & Lei Promulgada n. ${ }^{\circ} 121$ & 2012 \\
\hline Ceará & Lei n. ${ }^{\circ} 15036$ & 2011 \\
\hline Distrito Federal & Lei n. ${ }^{\circ} 2949$ & 2002 \\
\hline Goiás & Lei n. ${ }^{\circ} 18456$ & 2014 \\
\hline Mato Grosso do Sul & Lei $n .^{\circ} 2310$ & $2001 / 2013$ \\
\hline Minas Gerais & Lei Complementar n. ${ }^{\circ} 116$ & 2011 \\
\hline Paraíba & Lei Complementar n. ${ }^{\circ} 127$ & 2015 \\
\hline Pernambuco & Lei n. $^{\circ} 13.314$ & 2007 \\
\hline Rio de Janeiro & Lei n. ${ }^{\circ} 3921$ & 2002 \\
\hline Rio Grande do Sul & Lei n. ${ }^{\circ} 12561$ & 2006 \\
\hline Rondônia & Lei n. ${ }^{\circ} 1860$ & 2008 \\
\hline São Paulo & Lei n. ${ }^{\circ} 12250$ & 2006 \\
\hline
\end{tabular}

Fonte: elaborado pelos autores

No Quadro 1, nota-se que mais da metade das leis são datadas a partir de 2011, com destaque para a alteração integral em 2013 da lei estadual do Mato Grosso do Sul, Lei n. ${ }^{\circ} 2.310$, de 2001. Tal constatação justifica-se, sobretudo, pela popularização do tema na última década, por parte dos pesquisadores e, principalmente, pela divulgação da mídia, a qual auxilia em uma "pressão" para uma resposta dos órgãos de controle e políticos, por exemplo.

\subsection{Categorias de assédio moral}

Nesta subseção passa-se a tratar dos tipos de assédio abrangidos tendo como base as categorias de Hirigoyen (2006) adaptadas para esta pesquisa, a saber: deterioração proposital das condições de trabalho; isolamento e recusa de comunicação; atentado contra a dignidade; violência verbal e física; assédio sexual; e previsão especial para pessoas de grupos historicamente discriminados. 
Iniciando pela categoria Deterioração proposital das condições de trabalho, só foi previsto no Rio Grande do Sul, que não colocou em sua legislação as hipóteses de assédio moral, conforme pode ser observado no quadro abaixo:

Quadro 2 - Deterioração proposital das condições de trabalho

\begin{tabular}{|c|c|}
\hline ESTADO & DESTAQUE NA LEGISLAÇÃO \\
\hline $\begin{array}{c}\text { Amapá; } \\
\text { Minas Gerais }\end{array}$ & $\begin{array}{l}\text { Atribuir, de modo frequente, ao agente público, função incompatível com sua formação } \\
\text { acadêmica ou técnica especializada ou que dependa de treinamento; }\end{array}$ \\
\hline $\begin{array}{l}\text { Amazonas; } \\
\text { Goiás; } \\
\text { Mato Grosso do Sul; } \\
\text { Rio de Janeiro; } \\
\text { Rondônia; } \\
\text { São Paulo }\end{array}$ & $\begin{array}{l}\text { Determinar o cumprimento de atividades incompatíveis com o cargo do servidor em } \\
\text { detrimento de suas atribuições ou em condições e prazos inexequíveis; designar } \\
\text { funções triviais de modo sistemático a servidor ocupante de cargo técnico, analista, } \\
\text { especialista ou aqueles para as quais, de qualquer forma, sejam exigidos treinamento } \\
\text { e conhecimentos específicos; sonegar de informações que sejam necessárias ao } \\
\text { desempenho de suas funções ou úteis a sua vida funcional; }\end{array}$ \\
\hline Ceará & $\begin{array}{l}\text { Exigir, sem aquiescência do servidor público, com ou sem ameaça, o cumprimento } \\
\text { de atribuições estranhas ou de atividades incompatíveis com as suas atribuições, } \\
\text { em condições e prazos inexequíveis, com o intuito de menosprezá-lo; exigir, sob } \\
\text { reiteradas ameaças, o exercício de funções triviais ao exercente de funções técnicas, } \\
\text { especializadas, ou aquelas para as quais, de qualquer forma, exijam treinamento } \\
\text { e conhecimentos específicos; sonegar de informações que sejam necessárias ao } \\
\text { desempenho de suas funções ou úteis a sua vida funcional; }\end{array}$ \\
\hline Distrito Federal & $\begin{array}{l}\text { Exigir do subordinado, com o intuito de menosprezá-lo, tarefas incompatíveis com as } \\
\text { funções para as quais foi contratado; }\end{array}$ \\
\hline Paraíba & $\begin{array}{l}\text { Retirar da vítima a autonomia própria do cargo que exerce; privá-la de acesso a } \\
\text { instrumentos e equipamentos adequados para execução do trabalho; dar-lhe } \\
\text { permanentemente atribuições estranhas ao cargo que exerce; atribuir-lhe proposital } \\
\text { e sistematicamente tarefas superiores às suas competências; induzir a vítima ao erro; } \\
\text { contar o tempo de permanência ou limitar o número de vezes em que o trabalhador vai } \\
\text { ao banheiro; atribuir tarefas humilhantes; proporcionar condições de trabalho piores } \\
\text { do que aquelas garantidas a outros servidores que desempenham funções correlatas; } \\
\text { não Ihe transmitir informações úteis e necessárias para a realização de tarefas; não } \\
\text { repassar o trabalho, deixando o trabalhador ocioso; atribuir à vítima tarefas incompatíveis } \\
\text { com sua saúde e condição; }\end{array}$ \\
\hline Pernambuco & $\begin{array}{l}\text { Cumprimento de atribuições incompatíveis com o cargo ocupado ou em condições } \\
\text { adversas ou com prazos insuficientes; exercício de funções triviais para quem exerce } \\
\text { funções técnicas e especializadas; reiteração de críticas e comentários improcedentes ou } \\
\text { subestimação de esforços; sonegação de informações indispensáveis ao desempenho } \\
\text { das suas funções. }\end{array}$ \\
\hline
\end{tabular}

Fonte: Elaborado pelos autores.

É possivel observar que todas as legislações apresentam dispositivos relacionados com a determinação de tarefas aquém ou além daquelas que o trabalhador está preparado para exercer, o que transmite, tanto para a pessoa quanto para seus colegas, a mensagem de que esta seria incompetente, encaixando no que Hirigoyen (2006) define como deterioração das condições de trabalho. Nota-se um desvio maior na legislação da Paraíba (2015), que prevê também a indução ao erro, a retirada de autonomia, a restrição a objetos necessários ao trabalho e até mesmo a restrição da utilização de banheiro.

As situações de deterioração proposital das condições de trabalho, conforme visualizado na literatura e nas práticas vivenciadas por diversas vítimas, são situações que se confundem com aspectos relacionados ao próprio desenvolvimento do trabalho (Hirigoyen, 2006; Nunes \& Tolfo, 2015), o que leva muitos trabalhadores a duvidarem se realmente estão sendo assediados, devido a sutileza com que essas situações são efetuadas no ambiente laboral.

Já com relação à categoria Isolamento e recusa de comunicação, além do Rio Grande do Sul, não foram identificados dispositivos nas leis do Distrito Federal e de Pernambuco, conforme pode ser observado a seguir. 
Quadro 3 - Isolamento e recusa de comunicação

\begin{tabular}{|c|l|}
\hline ESTADO & \multicolumn{1}{c|}{ DESTAQUE NA LEGISLAÇÃO } \\
\hline $\begin{array}{c}\text { Amapá; } \\
\text { Minas Gerais }\end{array}$ & $\begin{array}{l}\text { Isolar ou incentivar o isolamento de agente público, privando-o de informações, treinamentos } \\
\text { necessários ao desenvolvimento de suas funções ou do convívio com seus colegas; relegar } \\
\text { intencionalmente o agente público ao ostracismo; }\end{array}$ \\
\hline $\begin{array}{c}\text { Amazonas; } \\
\text { Mato Grosso do Sul; } \\
\text { Rio de Janeiro; } \\
\text { Rondônia }\end{array}$ & $\begin{array}{l}\text { Torturar psicologicamente, desprezar, ignorar ou humilhar o servidor, isolando-o de contatos } \\
\text { com seus colegas e superiores hierárquicos ou com outras pessoas com as quais se relacione } \\
\text { funcionalmente; }\end{array}$ \\
\hline $\begin{array}{c}\text { Ceará; } \\
\text { Goiás; }\end{array}$ & $\begin{array}{l}\text { Desprezar, ignorar ou humilhar o servidor, de forma que o isole de contatos com outros } \\
\text { servidores de qualquer nível, sujeitando-o a receber informações, atribuições, tarefas e outras } \\
\text { atividades através de terceiros ou por quaisquer outros meios; }\end{array}$ \\
\hline Paraíba & $\begin{array}{l}\text { Omitir-se de se comunicar com a vítima, fazendo-o unicamente por escrito; separar } \\
\text { injustificadamente a vítima dos colegas de trabalho; proibir os colegas de falarem com a vítima. }\end{array}$ \\
\hline
\end{tabular}

Fonte: Elaborado pelos autores.

O isolamento, bem como a recusa de fala, consiste em uma hipótese de exclusão social da vítima, que sofre danos psicológicos ao ser alijada do convívio social (Hirigoyen, 2006). Desse modo, as legislações acima preveem tanto a recusa de informações funcionais quanto do convívio social dentro da organização. Observa-se que, ainda nesta categoria, o assédio moral pode ser interpretado como questões "normais" no ambiente laboral.

Com relação à categoria Atentado contra a dignidade, apenas os estados de Pernambuco e do Rio Grande do Sul não possuem dispositivos aderentes.

Quadro 4 - Atentado contra a dignidade

\begin{tabular}{|c|c|}
\hline ESTADO & DESTAQUE NA LEGISLAÇÃO \\
\hline Amapá & $\begin{array}{l}\text { Manifestar-se jocosamente em detrimento da imagem de agente público, submetendo-o a } \\
\text { situação vexatória, ou fomentar boatos inidôneos e comentários maliciosos; }\end{array}$ \\
\hline $\begin{array}{l}\text { Amazonas; } \\
\text { Mato Grosso do Sul; } \\
\text { Rio de Janeiro }\end{array}$ & $\begin{array}{l}\text { Divulgar rumores e comentários maliciosos, bem como críticas reiteradas, ou subestimar } \\
\text { esforços, que atinjam a saúde mental do servidor; }\end{array}$ \\
\hline Ceará & $\begin{array}{l}\text { Divulgar rumores e comentários maliciosos, bem como críticas reiteradas, ou subestimar } \\
\text { esforços, com a intenção de atingir a dignidade do servidor; expor o servidor a situações } \\
\text { adversas, com efeitos físicos ou mentais, culminando em prejuízos do seu desenvolvimento } \\
\text { pessoal, profissional ou financeiro; }\end{array}$ \\
\hline Distrito Federal & $\begin{array}{l}\text { Desqualificar o subordinado por meio de palavras, gestos ou atitudes tratar o subordinado por } \\
\text { apelidos ou expressões pejorativas; }\end{array}$ \\
\hline Goiás & $\begin{array}{l}\text { Divulgação de rumores e comentários maliciosos, ou o fomento de boatos inidôneos em detrimento } \\
\text { da imagem do agente público, bem como a prática de críticas reiteradas ou subestimação de } \\
\text { esforços, que atinjam a dignidade do agente público; }\end{array}$ \\
\hline Minas Gerais & $\begin{array}{l}\text { Manifestar-se jocosamente em detrimento da imagem de agente público, submetendo-o a situação } \\
\text { vexatória, ou fomentar boatos inidôneos e comentários maliciosos; desqualificar, reiteradamente, } \\
\text { por meio de palavras, gestos ou atitudes, a autoestima, a segurança ou a imagem de agente } \\
\text { público, valendo-se de posição hierárquica ou funcional superior, equivalente ou inferior; }\end{array}$ \\
\hline Paraíba & $\begin{array}{l}\text { Contestar sistematicamente todas as suas decisões; criticar seu trabalho de forma injusta ou } \\
\text { exagerada na presença de terceira pessoa; pressioná-la para que não faça valer seus direitos, } \\
\text { a exemplo de férias, horários, prêmios; interromper a fala da vítima constantemente; utilizar } \\
\text { de insinuações desdenhosas para desqualificar a vítima; fazer gestos de desprezo diante da } \\
\text { vítima, a exemplo de suspiros, olhares desdenhosos, levantar de ombros; propagar rumores } \\
\text { a respeito da vítima; }\end{array}$ \\
\hline Rondônia & $\begin{array}{l}\text { A exposição do funcionário, servidor ou empregado à situação humilhante ou constrangedora; } \\
\text { qualquer ação, palavra ou gesto praticado de modo repetitivo e prolongado, durante o expediente do } \\
\text { órgão ou entidade, por agente, delegado, chefe ou superior hierárquico ou qualquer representante } \\
\text { que, no exercício de suas funções, abusar da autoridade que lhe foi conferida; qualquer ação } \\
\text { ou palavra que tenha por objetivo ou efeito atingir a autoestima e a autodeterminação do } \\
\text { subordinado, com danos ao ambiente de trabalho, aos serviços prestados ao público; divulgar } \\
\text { rumores e comentários maliciosos, bem como críticas, reiteradas, ou subestimar esforços, que } \\
\text { atinjam a saúde mental do servidor e ao próprio usuário; }\end{array}$ \\
\hline São Paulo & $\begin{array}{l}\text { Na divulgação de rumores e comentários maliciosos, bem como na prática de críticas reiteradas } \\
\text { ou na de subestimação de esforços, que atinjam a dignidade do servidor. }\end{array}$ \\
\hline
\end{tabular}

Fonte: Elaborado pelos autores. 
Observa-se uma grande preocupação com a divulgação de rumores e comentários maliciosos, popularmente conhecido como boato, bem como com a crítica reiterada e pública contra a vítima. Tratam-se de atos de desprezo, de desqualificação ou chacotas contra a vítima (Hirigoyen, 2006), que, nesse caso, evolui para ataques mais visíveis e violentos (Einarsen et al., 2011; Nunes \& Tolfo, 2015), ao contrário dos anteriores, em que a visibilidade é mais difícil de se identificar.

No caso da categoria violência verbal e física, há previsões apenas nos estados do Amazonas, Goiás, Paraíba, Pernambuco, Rio de Janeiro, Rondônia e São Paulo, conforme abaixo.

Quadro 5 - Violência verbal e física

\begin{tabular}{|c|l|}
\hline ESTADO & \multicolumn{1}{c|}{ DESTAQUE NA LEGISLAÇÃO } \\
\hline $\begin{array}{c}\text { Amazonas; } \\
\text { Rio de Janeiro; } \\
\begin{array}{c}\text { Rondônia; } \\
\text { São Paulo }\end{array}\end{array}$ & $\begin{array}{l}\text { Na exposição intencional do servidor ou do funcionário a efeitos físicos ou mentais adversos, } \\
\text { em prejuízo de seu desenvolvimento pessoal e profissional; }\end{array}$ \\
\hline Goiás & $\begin{array}{l}\text { Expor o agente público a efeitos físicos ou mentais adversos, em prejuízo de seu desenvolvimento } \\
\text { pessoal e profissional; valer-se do cargo para induzir o agente público a relações pessoais } \\
\text { involuntárias ou persuadi-lo a praticar atos ilegais ou deixar de praticar ato determinado em lei; }\end{array}$ \\
\hline Paraíba & $\begin{array}{l}\text { Atribuir à vítima, contra a vontade dela, trabalhos perigosos; causar danos morais, psicológicos, } \\
\text { físicos entre outros, em seu trabalho; praticar violência verbal, física ou sexual; ameaçar de } \\
\text { violência física ou sexual; }\end{array}$ \\
\hline Pernambuco & Submissão a efeitos físicos e mentais prejudiciais ao seu desenvolvimento pessoal e profissional. \\
\hline
\end{tabular}

Fonte: Elaborado pelos autores.

Trata-se da forma mais visível e violenta de assédio, podendo se enquadrar em vários crimes tipificados no Código Penal, como lesão corporal (Art. 129), assédio sexual (Art. 216-A) ou mesmo estupro (Art. 213). Como pode ser observado, são listadas formas de assédio relacionadas à exposição a riscos físicos ou mentais, violência propriamente dita, bem como manutenção de relações involuntárias e violência sexual.

Por fim, no caso de dispositivos voltados para grupos historicamente discriminados (mulheres, negros, pessoas com deficiência, entre outros), há dispositivos específicos no Amapá, Goiás, Minas Gerais e Paraíba, como pode ser observado abaixo.

Quadro 6 - Grupos historicamente discriminados

\begin{tabular}{|c|l|}
\hline ESTADO & \multicolumn{1}{|c|}{ DESTAQUE NA LEGISLAÇÃO } \\
\hline $\begin{array}{c}\text { Amapá; } \\
\text { Goiás; } \\
\text { Minas Gerais }\end{array}$ & $\begin{array}{l}\text { Desrespeitar limitação individual de agente público, decorrente de doença física ou psíquica, } \\
\text { atribuindo-lhe atividade incompatível com suas necessidades especiais; preterir o agente público, } \\
\text { em quaisquer escolhas, em função de raça, sexo, nacionalidade, cor, idade, religião, posição } \\
\text { social, preferência ou orientação política, sexual ou filosófica; }\end{array}$ \\
\hline Paraíba & $\begin{array}{l}\text { Zombar sobre deficiências físicas ou sobre aspectos físicos da vítima; ridicularizar as crenças } \\
\text { religiosas ou convicções políticas da vítima; }\end{array}$ \\
\hline
\end{tabular}

Fonte: Elaborado pelos autores.

Embora muitos desses grupos minoritários já tenham alguma legislação específica, observaram-se poucos estados que enfatizam ainda mais nas legislações sobre assédio moral. Nota-se uma preocupação com vários aspectos da vida social que possam gerar atos de assédio, perpassando deficiências, aspectos físicos, de gênero, de origem, de idade, de religião, entre vários outros. Enfatizamos que o assédio moral pode se manifestar pela recusa de uma diferença ou também partir de um processo de discriminação do outro ou de suas características, que pode incidir nos agrupamentos/elementos mencionados anteriormente (Hirigoyen, 2006; Freitas et al., 2008).

Ademais, cabe ressaltar a importância na área de gestão de pessoas em discutir e avançar no sentido de reduzir os fatores que podem levar a ocorrência do assédio moral, sexual e outros tipos de violência dentro das organizações. Logo, é importante que desenvolvam mecanismos para identificar estas e outras práticas ressaltadas ao longo desta subseção para prevenir e combater a violência. 
Em geral, observa-se que as legislações mais recentes possuem uma maior aderência com relação à teoria que as mais antigas. Tal afirmação, tal como ora se sugere, pode encontrar respaldo no notório fato de que a matéria vem sendo cada vez mais debatida pelos pesquisadores, o que torna mais qualificado o conteúdo da norma em elaboração. Além do próprio sistema jurídico, principalmente do trabalho, que vem desenvolvendo ações de fiscalização e punição nas mais diversas organizações.

\subsection{Denúncia, apuração e punição}

Acertada a etapa das categorias de assédio moral, passa-se a analisar o sistema de denúncia, apuração e punição do assédio moral. Na categoria meio especial para denúncia, o único estado a prever por meio de lei um método diverso do processo administrativo convencional foi o Ceará, que previu a instituição e competência para recebimento de denúncias da Comissão de Prevenção e Combate ao Assédio Moral, que estaria presente em todos os órgãos da administração estadual.

Já no caso da apuração e repreensão, os estados, em geral, previram instauração de Processo Administrativo Disciplinar pela autoridade competente e punição com multa, repreensão, suspensão e demissão, sendo o único estado a prever algo diferente o Ceará, que previu esse processamento pela Comissão de Prevenção e Combate ao Assédio Moral.

O sistema de denúncia do assédio moral precisa ser devidamente estruturado para que possa atender, de forma eficiente, a vítima e a instituição. Deve-se garantir o sigilo e que os casos serão tratados de forma isonômica e justa (Einarsen \& Hoel, 2008). Portanto, não basta apenas existir, deve-se criar uma estrutura para que determinada comissão ou grupo que trabalhe com a temática possa realizar suas atividades de forma ética e sem influências, garantindo a proteção da vítima e a punição dos envolvidos quando constatado a violência (Nunes, 2016). Dessa forma, a impunidade e o corporativismo presentes nas relações, nas organizações e na sociedade acabam por não prejudicar o correto e justo funcionamento e desenvolvimento das atividades dessas comissões e grupos.

\subsection{Previsão de apoio às vítimas}

Nesta subseção, de Previsão de apoio às vítimas de assédio moral, foram identificados dispositivos nas legislações dos estados do Amapá, Goiás, Minas Gerais e Ceará, prevendo o acompanhamento psicológico dos sujeitos passivos e ativos do caso de assédio, conforme apresentado no Quadro 7, a seguir.

Quadro 7 - Apoio à vítima

\begin{tabular}{|c|l|}
\hline ESTADO & \multicolumn{1}{c|}{ DESTAQUE NA LEGISLAÇÃO } \\
\hline $\begin{array}{c}\text { Amapá; } \\
\text { Minas Gerais }\end{array}$ & $\begin{array}{l}\text { Estado providenciará, na forma do regulamento, acompanhamento psicológico para os sujeitos } \\
\text { passivos de assédio moral, bem como para os sujeitos ativos, em caso de necessidade; }\end{array}$ \\
\hline Ceará & $\begin{array}{l}\text { O Instituto de Saúde dos Servidores do Estado do Ceará - ISSEC prestará a devida assistência } \\
\text { médica, psicológica e social gratuita aos servidores públicos que apresentarem transtornos físicos } \\
\text { e mentais decorrentes de assédio moral. } \\
\text { Diagnosticado em servidor público transtorno físico e mental decorrente de assédio moral no trabalho, } \\
\text { o ISSEC comunicará o fato ao dirigente máximo do órgão de onde provém o servidor e às comissões } \\
\text { de prevenção e combate ao assédio moral, sendo a comunicação juntada aos autos do procedimento; }\end{array}$ \\
\hline Goiás & $\begin{array}{l}\text { Acompanhamento psicológico aos sujeitos passivos, bem como aos ativos, quando necessário, na } \\
\text { forma que dispuser o regulamento. }\end{array}$ \\
\hline
\end{tabular}

Fonte: Elaborado pelos autores.

Apesar dos vários danos físicos, psicológicos e sociais que o assédio moral pode provocar (Hoel et al., 2001; Keashly \& Jagatic, 2003; Barreto, 2006; Nunes \& Tolfo, 2012; Vasconcelos, 2015), apenas quatro estados se preocuparam com a questão, sendo o estado do Ceará o único a prever a articulação com a saúde ocupacional dos servidores.

Observa-se, portanto, uma carência no aspecto de proteção ao trabalhador que é alvo dessa violência. Um indivíduo assediado pode desenvolver tanto consequências para sua saúde quanto ter reduzido seu desempenho no trabalho e adesão à organização (Nunes \& Tolfo, 2012). Nesse sentido, caberia a área de gestão de pessoas desenvolver estratégias para informar e minimizar os efeitos e o sofrimento dos 
trabalhadores, bem como construir mecanismos de fortalecimento psíquico e recuperação da sua saúde mental com profissionais qualificados, além da construção de instrumentos de prevenção e combate ao assédio moral.

\subsection{Previsão de instrumentos de prevenção}

Quanto à Previsão de instrumentos de prevenção, que visam estratégias para prevenir o assédio moral, só não são previstos na legislação do Distrito Federal. No Quadro 8, a seguir, são apresentadas as principais estratégias contidas nas legislações estaduais analisadas.

Quadro 8 - Instrumentos de prevenção

\begin{tabular}{|c|c|}
\hline ESTADO & DESTAQUE NA LEGISLAÇÃO \\
\hline Amapá & $\begin{array}{l}\text { Promoção de cursos de formação e treinamento visando à difusão das medidas preventivas e } \\
\text { à extinção de práticas inadequadas; promoção de debates e palestras, produção de cartilhas e } \\
\text { material gráfico para conscientização; acompanhamento de informações estatísticas sobre licenças } \\
\text { médicas concedidas em função de patologia associada ao assédio moral, para identificar setores, } \\
\text { órgão ou entidades nos quais haja indícios da prática de assédio moral; }\end{array}$ \\
\hline $\begin{array}{l}\text { Amazonas; } \\
\text { Mato Grosso do } \\
\text { Sul; } \\
\text { Pernambuco; } \\
\text { Rio de Janeiro; } \\
\text { Rio Grande do Sul; } \\
\quad \text { Rondônia }\end{array}$ & $\begin{array}{l}\text { Os órgãos ou entidades da administração pública estadual, bem como, concessionárias ou } \\
\text { permissionárias na pessoa de seus representantes legais, ficam obrigados a tomar as medidas } \\
\text { necessárias para prevenir o assédio moral no trabalho, conforme definido na presente lei; }\end{array}$ \\
\hline Ceará & $\begin{array}{l}\text { Fica instituído o Sistema de Prevenção e Combate ao Assédio Moral composto de uma Comissão } \\
\text { Central e de comissões setoriais; }\end{array}$ \\
\hline Goiás & $\begin{array}{l}\text { Promoção de cursos de formação e treinamento visando à difusão de medidas preventivas e } \\
\text { extinção de práticas inadequadas; promoção de debates e palestras, bem como a produção de } \\
\text { cartilhas e material gráfico para conscientização; promoção de treinamento para servidores que } \\
\text { atuem nas unidades setoriais de recursos humanos dos órgãos e entidades, com conteúdo que } \\
\text { possibilite identificar as condutas caracterizadas como assédio moral, promovendo o acolhimento da } \\
\text { vítima e prestando orientações a ela e ao agressor; acompanhamento de informações estatísticas } \\
\text { sobre licenças médicas concedidas em função de patologia associada ao assédio moral, para } \\
\text { identificar setores, órgãos ou entidades nos quais haja indícios da prática de assédio moral; }\end{array}$ \\
\hline Minas Gerais & $\begin{array}{l}\text { Promoção de cursos de formação e treinamento visando à difusão das medidas preventivas e } \\
\text { à extinção de práticas inadequadas; promoção de debates e palestras, produção de cartilhas e } \\
\text { material gráfico para conscientização; acompanhamento de informações estatísticas sobre licenças } \\
\text { médicas concedidas em função de patologia associada ao assédio moral, para identificar setores, } \\
\text { órgãos ou entidades nos quais haja indícios da prática de assédio moral; }\end{array}$ \\
\hline Paraíba & $\begin{array}{l}\text { Fica instituída, a Semana Estadual de Prevenção e Combate ao Assédio Moral, a ocorrer, anualmente, } \\
\text { no período de } 10 \text { a } 14 \text { de setembro, durante a qual serão realizados eventos institucionais, } \\
\text { seminários, palestras, ciclos de debates, simpósios, entre outros, buscando compartilhar ações } \\
\text { de prevenção e combate ao assédio moral entre todos os Poderes e unidades autônomas da } \\
\text { Administração Pública. Parágrafo único. Os eventos deverão contar com a participação de entidades } \\
\text { representativas dos servidores públicos, organizações governamentais e não governamentais, } \\
\text { instituições educacionais e demais setores interessados na temática; }\end{array}$ \\
\hline São Paulo & $\begin{array}{l}\text { Os órgãos da administração pública estadual direta, indireta e fundações públicas, na pessoa de } \\
\text { seus representantes legais, ficam obrigados a tomar as medidas necessárias para prevenir o assédio } \\
\text { moral, conforme definido na presente lei. Para os fins deste artigo serão adotadas, dentre outras, } \\
\text { as seguintes medidas: o planejamento e a organização do trabalho: a) levará em consideração a } \\
\text { autodeterminação de cada servidor e possibilitará o exercício de sua responsabilidade funcional } \\
\text { e profissional; b) dará a ele possibilidade de variação de atribuições, atividades ou tarefas } \\
\text { funcionais; c) assegurará ao servidor oportunidade de contatos com os superiores hierárquicos } \\
\text { e outros servidores, ligando tarefas individuais de trabalho e oferecendo a ele informações } \\
\text { sobre exigências do serviço e resultados; d) garantirá a dignidade do servidor; o trabalho pouco } \\
\text { diversificado e repetitivo será evitado, protegendo o servidor no caso de variação de ritmo de } \\
\text { trabalho; as condições de trabalho garantirão ao servidor oportunidades de desenvolvimento } \\
\text { funcional e profissional no serviço. }\end{array}$ \\
\hline
\end{tabular}

Fonte: Elaborado pelos autores. 
As medidas apresentadas nas legislações dos estados do Amazonas, Mato Grosso do Sul, Pernambuco, Rio de Janeiro, Rio Grande do Sul e Rondônia são genéricas. Elas “jogam” o desenvolvimento de estratégias para seus órgãos realizarem da forma que entendem.

Em outros casos são detalhadas as medidas, como promoção de cursos de formação e treinamento, cartilhas, debates e palestras, ou mesmo a semana dedicada ao tema, como nos casos do Amapá, Goiás e Paraíba, tendo sido criado um Sistema de Prevenção e Combate ao Assédio Moral, composto de uma comissão central e de comissões setoriais no caso do estado do Ceará. Nesses casos, a estratégia é a informação e a capacitação dos trabalhadores como uma forma de conscientizar sobre a violência, o que, para Nunes (2016), é uma importante estratégia para reduzir e informar sobre o que é, de fato, o assédio moral, seu conceito, as características, as formas em que a violência acontece e seus desdobramentos.

Nunes, Tolfo e Espinosa (2019) comentam que as estratégias de prevenção e combate ao assédio moral vão além de apenas divulgar o tema, que é uma ação fundamental. Para os autores, devem-se englobar aspectos relacionados ao próprio indivíduo, seu comportamento e ações no ambiente laboral (respeito ao outro e valores, por exemplo), além de elementos culturais e práticas organizacionais (formação de chefias, aplicação e controle do código de ética e normativas, maior divulgação do assédio e criação de comissões, por exemplo). Portanto, enfatizam que não se trata apenas de assédio, mas de comportamentos e práticas antiéticas, negativas, que precisam ser mudadas e transformadas para práticas mais saudáveis e éticas.

Por fim, nos últimos anos observamos uma crescente mobilização social e divulgação midiática sobre violência, igualdade, justiça, direitos e demais temas - os quais estão relacionados ao assédio moral e nos levam a repensar práticas e comportamentos. Essa "comoção" acaba pressionando o Estado para agir em prol da saúde, da segurança e do bemestar do indivíduo. Portanto, acreditamos que cada vez mais novas legislações serão desenvolvidas e que estas aqui analisadas serão aperfeiçoadas de modo a garantir os direitos para aqueles que são alvos e punições para os agressores. Não obstante, acreditamos que práticas e comportamentos éticos e a incorporação de bons valores nos relacionamentos e nas atividades laborais, por exemplo, podem favorecer ainda mais para que situações de assédio moral não ocorram ou se perpetuem.

\section{Considerações finais}

Observou-se que as legislações em âmbito estadual vêm evoluindo consideravelmente nesta década, tendo mais que dobrado em quantitativo. Todavia o fato de quase a metade dos estados ainda não possuírem legislação específica contra o assédio moral demonstra que ainda há muito a avançar junto aos estados federados.

Sobre as definições do que é assédio moral, observa-se que no caso das categorias deterioração proposital das condições de trabalho, isolamento e recusa de comunicação e atentado contra a dignidade, há uma maior compreensão pelos estados federados, conquanto as categorias violência verbal e física, assédio sexual e previsão especial para pessoas de grupos historicamente discriminados ainda são pouco abrangidas pelos estados. Uma hipótese para essa não classificação que poderia ser investigada por trabalhos futuros é que, por tais fatos poderem ser classificados como crimes, os legisladores tenham optado por não os incluírem, apesar da punição administrativa não se confundir com a penal.

No caso do sistema de denúncia, apuração e punição do assédio moral, destaca-se a legislação do Ceará na temática, podendo ser estudada comparativamente para verificar se o estabelecimento de Comissão de Prevenção e Combate ao Assédio Moral gera reações diversas das encontradas em outros estados. No caso dos instrumentos de prevenção e apoio às vítimas, observa-se um foco maior na prevenção, de tal sorte que apenas quatro estados preveem o acompanhamento das vítimas.

Embora tenha sido identificada uma gama de legislações sobre a temática, as quais são importantes para a proteção e amparo dos indivíduos envolvidos - em especial, as vítimas -, questionamos até que ponto elas são efetivamente funcionais e aplicadas, uma vez que a própria cultura nacional, que influência práticas e comportamentos organizacionais, apresenta traços de impunidade, que alimenta todo um processo de "ismos" nas relações, como corporativismo, favoritismo, personalismo. 
Compreendemos que o debate sobre a legislação para o desenvolvimento da teoria sobre a temática é fundamental. Provar que o assédio ocorreu é uma ação difícil, pois a própria violência é, muitas vezes, velada. Observar que a ação do estado em legislações para proteção ao trabalhador é um importante movimento que precisa ser identificado, analisado e divulgado para a sociedade e meio acadêmico.

Pelo assédio moral ser um tema e uma prática que envolve outras ciências (psicologia, administração, direito, medicina, enfermagem e demais), compreender suas características e repercussões, por exemplo, é fundamental para qualquer indivíduo. Pensar na questão do assédio sob a ótica da administração envolve compreender o que é, elementos presentes nas práticas e cultura organizacional que o influenciam, o sistema de denúncias/ouvidoria, os mecanismos de apoio à vítima, as práticas de prevenção e combate, e outras ações. Assim sendo, são ações que perpassam todos os setores organizacionais e, em especial, a área de gestão de pessoas.

Os resultados obtidos em virtude da investigação promovida servirão para novos estudos no campo da administração. Seria possível realizar investigações acerca da incidência das principais condutas classificadas na legislação estudada, como assédio moral. Tal pesquisa poderia se valer, por exemplo, da análise de eventuais denúncias e/ou condenações por assédio nas entidades e/ou nos órgãos a serem estudados. No campo prático, por sua vez, os dados obtidos a partir da presente investigação jurídico-comparativa poderão contribuir para que sejam implementadas novas políticas de combate ao assédio moral ou adaptadas as já existentes. No âmbito da administração privada, por exemplo, os tipos normativos estudados podem servir como modelo para eventuais códigos de ética e de postura nas empresas, especialmente por conterem descrições de condutas - por mais sutis que possam parecer - que revelem práticas de assédio moral. Já no campo da administração pública, reconhecendo o papel de destaque do administrador durante as fases de planejamento e de execução das políticas públicas, acredita-se que a compreensão crítica das estratégias já adotadas em outros estados brasileiros servirá como ponto de partida para gestores estaduais, municipais e federais aprimorem o combate ao assédio moral.

Por fim, como sugestões de pesquisas futuras, indicamos a verificação sobre a efetividade das legislações estaduais de assédio moral existentes. Dessa forma, a principal lacuna deste trabalho e que pode ser investigada por pesquisas futuras é a efetividade das leis por meio da comparação entre estados que possuem e que não possuem leis específicas em seu ordenamento jurídico.

\section{Referências}

Alcadipani, R., \& Crubellate, J. M. (2003). Cultura organizacional: generalizações improváveis e conceituações imprecisas. Revista de Administração de Empresas, 43(2), 64-77.

Barreto, M. M. S. (2003). Violência, saúde e trabalho: Uma jornada de humilhações. São Paulo: EDUC.

Bauer, M. W. (2003). Análise de conteúdo clássica: uma revisão. In Bauer, M. W., \& Gaskell, G. (Org.). Pesquisa qualitativa com som, imagem e texto (pp. 189-221). $2^{\mathrm{a}}$ ed. Vozes, Petrópolis.

BRASIL (1988). Constituição da República Federativa do Brasil. Brasília, DF: Senado Federal: Centro Gráfico.

Carbone, P. (2000). Cultura organizacional do setor público brasileiro: desenvolvendo uma metodologia de gerenciamento da cultura. Revista de Administração Pública, 34(2), 1-5.

Chapadeiro, B. (2015). Relato de caso de assédio moral num hospital público de SP: entre o (des) serviço e a (in)justiça. In: Gediel, J. A. P., Silva, E. F., Zanin, F., \& Mello L. E. (Orgs.). Estado, poder e assédio: relações de trabalho na administração pública (pp. 163-183). Curitiba: Kairós Edições.

Dallegrave Neto, J. A. (2013). O Assédio Sexual e Moral e a sua Prova na Justiça do Trabalho. Revista Eletrônica Tribunal Regional do Trabalho do Paraná, 2(16), 9-28.

Einarsen, S., \& Hoel, H. (2008). Bullying and mistreatment at work: How managers may prevent and manage such problems. In Kinder, A., Hughes, R., \& Cooper, C. L. (Eds.), Employee well-being and support: A workplace resource (pp. 161-173). Chichester, UK: John Wiley. 
Einarsen, S., Hoel, H., Zapf, D., \& Cooper, C. L. (2005). Workplace Bullying: individual pathology or organizational culture? In: Bowie, V., Fischer, B. S., \& Cooper, C. L. (Eds.). Workplace Violence: issues, trends, strategies (pp. 229-247). Devon: Willian Publishing.

Einarsen, S., Hoel, H., Zapf, D., \& Cooper, C. L. (2011). The concept of bullying and harassment at work: the European tradition. In: Einarsen, S., Hoel, H., Zapf, D., \& Cooper, C. L. (Orgs.). Bullying and Harassment in the Workplace: Developments in Theory, Research, and Practice (pp. 3-39). London: Taylor \& Francis.

Freitas, M. E. (2001). Assédio moral e assédio sexual: faces do poder perverso nas organizações. Revista de Administração de Empresas, 41(2), 8-19.

Freitas, M. E. (2007). Quem paga a conta do assédio moral no trabalho?. RAE-eletrônica, 6(1), 1-7.

Freitas, M. E.; Heloani, R., \& Barreto, M. (2008). Assédio moral no trabalho. São Paulo: Cengage Learning.

Gil, A. C. (2002). Como elaborar projetos de pesquisa. 4. Ed. São Paulo: Atlas.

Guimarães, L. R., \& Emmendoerfer, M. L. (2015). Caso UFV: ouvintes dos casos de assédio moral. In: Emmendoerfer, M. L., Tolfo, S. R., \& Nunes, T. S. (Orgs.). Assédio moral em organizações públicas e a (re)ação dos sindicatos (pp. 134-162). Curitiba: CRV.

Gonçalves, W. J. (2009). Discriminação contra a mulher obesa e assédio moral genérico: tutela efetiva da igualdade no processo de reversibilidade de conduta uma questão de direitos fundamentais. Desafio: Revista de Economia e Administração, 10(22), 67-82.

Gustin, M., \& Dias, M. T. (2002). Repensando a pesquisa jurídica. Belo Horizonte: Del Rey.

Harrington, S., Warren, S., \& Rayner, C. (2015). Human Resource Management practitioners' responses to workplace bullying: Cycles of symbolic violence. Organization, 22(3), 368-389.

Heloani, R. (2004). Assédio moral - Um ensaio sobre a expropriação da dignidade no trabalho. RAEeletrônica, 3(1), 1-8.

Heloani, R. (2005). Assédio moral: A dignidade violada. Aletheia, 22,101-108.

Heloani, R., \& Barreto, M. (2018). Assédio moral: gestão por humilhação. Curitiba, Juruá.

Hirigoyen, M-F. (2006). Mal-estar no trabalho: redefinindo o assédio moral. 3. ed. Rio de Janeiro:

Bertrand Brasil.

Höel, H., Sparks, K., \& Cooper, C. (2001). The cost of violence/stress at work and the benefits of a violence/stress-free working environment. Geneva: International Labour Organization.

Keashly, L., \& Jagatic, K. (2003). By any other name: American perspectives on workplace bullying. In Einarsen, S., Hoel, H. Zapf, D. \& Cooper, C. L. (Eds.), Bullying and emotional abuse in the workplace: International perspectives in research and practice (pp. 31-91). London, UK: Taylor and Francis.

Lei 13.314, de 15 de outubro de 2007. (2007, 15 outubro). Dispõe sobre o assédio moral no âmbito da Administração Pública Estadual direta, indireta e Fundações Públicas. Diário Oficial do Estado, Recife.

Lei Complementar $n^{\circ}$ 116, de 11 de janeiro de 2011. (2011, 11 janeiro). Dispõe sobre a prevenção e a punição do assédio moral na administração pública estadual. Diário Oficial do Estado, Belo Horizonte.

Lei Complementar $n^{\circ}$ 127, de 20 de janeiro de 2015. (2015, 20 janeiro). Dispõe sobre o assédio moral no âmbito da administração pública estadual e dá outras providências. Diário Oficial do Estado, João Pessoa.

Lei $n^{\circ} 121$, de 28 de setembro de 2012. (2012, 28 setembro). Veda o assédio moral no trabalho, no âmbito dos órgãos, repartições ou entidades da administração centralizada, autarquias, fundações empresas públicas e sociedades de economia mista, do Poder Legislativo, Executivo ou Judiciário 
do Estado do Amazonas, e concessionárias e permissionárias de serviços estaduais de utilidade ou interesse público inclusive, e dá outras providências. Diário Oficial do Estado, Manaus.

Lei $n^{\circ}$ 12250, de 09 de fevereiro de 2006. (2006, 09 fevereiro). Veda o assédio moral no âmbito da administração pública estadual direta, indireta e fundações públicas Diário Oficial do Estado, São Paulo.

Lei $n^{\circ} 12561$, de 12 de julho de 2006. (2006, 12 julho). Proíbe a prática do assédio moral no âmbito da administração pública estadual. Diário Oficial do Estado, Porto Alegre.

Lei $n^{\circ} 15036$, de 18 de novembro de 2011. (2011, 18 novembro). Dispõe sobre o assédio moral no âmbito da administração pública estadual e seu enfrentamento, visando a sua prevenção, repreensão e promoção da dignidade do agente público no ambiente de trabalho, e dá outras providências. Diário Oficial do Estado, Fortaleza.

Lei no 1818, de 22 de abril de 2014. (2014, 22 setembro). Dispõe sobre a prevenção e a punição ao assédio moral na Administração Pública do Estado do Amapá. Diário Oficial do Estado, Macapá.

Lei $n^{\circ}$ 18456, de 30 de abril de 2014. (2014, 30 abril). Dispõe sobre a prevenção e a punição de assédio moral no âmbito da Administração estadual e dá outras providências. Diário Oficial do Estado, Goiânia.

Lei $n^{\circ}$ 1860, de 10 de janeiro de 2008. (2008, 10 janeiro). Veda o assédio moral no trabalho, no âmbito dos órgãos, repartições ou entidades da administração centralizada, autarquias, fundações, empresas públicas e sociedades de economia mista, do Poder Legislativo, Executivo e Judiciário do Estado de Rondônia, inclusive concessionárias e permissionárias de serviços estaduais de utilidade ou interesse público, e dá outras providências. Diário Oficial do Estado, Porto Velho.

Lei $n^{\circ} 2310$, de 9 de outubro de 2001. (2001, 9 outubro). Dispõe sobre a aplicação de penalidades à prática de assédio moral no âmbito da Administração Pública Estadual, e dá outras providências. Diário Oficial do Estado, Campo Grande.

Lei $\mathrm{n}^{\circ}$ 2949, de 19 de abril de 2002 (2002, 19 abril). Determina sanções à prática de assédio moral. Diário Oficial do Estado, Brasília.

Lei $\mathrm{n}^{\circ}$ 3921, de 23 de agosto de 2002. (2002, 23 agosto). Veda o assédio moral no trabalho, no âmbito dos órgãos, repartições ou entidades da administração centralizada, autarquias, fundações, empresas públicas e sociedades de economia mista, do poder legislativo, executivo ou judiciário do estado do rio de janeiro, inclusive concessionárias e permissionárias de serviços estaduais de utilidade ou interesse público, e dá outras providências. Diário Oficial do Estado, Rio de Janeiro.

Martiningo Filho, A., \& Siqueira, M. V. S. (2008). Assédio moral e gestão de pessoas: uma análise do assédio moral nas organizações e o papel da área de gestão de pessoas. Revista de Administração Mackenzie, 9(5), 11-34.

Nogueira, R. M., Carvalho Neto, A. M., \& Nunes, T. S. (2018). A Negociação Coletiva e Assédio Moral no Brasil: Alguma Luz no Fim do Túnel?. REAd. Revista Eletrônica de Administração, 24(3), 21-45.

Nunes, T. S. (2016). A influência da cultura organizacional na ocorrência do assédio moral no trabalho na Universidade Federal de Santa Catarina. (Tese). Programa de Pós-Graduação em Administração, Universidade Federal de Santa Catarina, Florianópolis, Santa Catarina, Brasil.

Nunes, T. S., \& Tolfo, S. R. (2012). Assédio moral no trabalho: consequências identificadas por servidores docentes e técnico-administrativos em uma universidade federal brasileira. Revista Gestão Universitária na América Latina - GUAL, 5(3), 264-286.

Nunes, T. S., \& Tolfo, S. R. (2013). Assédio moral em universidade: as possíveis consequências em comentar e/ou denunciar a violência. Administração Pública e Gestão Social, 5(4), 148-155.

Nunes, T. S., \& Tolfo, S. R. (2015). O assédio moral no contexto universitário: uma discussão necessária. Revista de Ciências da Administração, 17(41), 21-36.

Nunes, T. S., Tolfo, S. R., \& Espinosa, L. M. C. (2018). Assédio moral no trabalho: a compreensão dos 
trabalhadores sobre a violência. Revista de Gestão e Secretariado, 9(2), 205-219.

Nunes, T. S., Tolfo, S. R., \& Espinosa, L. M. C. (2019). A percepção de servidores universitários sobre as políticas, ações e discursos institucionais sobre o assédio moral no trabalho. Organizações em contexto, 15(9), 191-222.

Prates, M. A. S. \& Barros, B. T. (1997) O estilo brasileiro de administrar: sumário de um modelo de ação cultural brasileiro com base na gestão empresarial. In: Motta, F. C. P.; \& Caldas, M. P. (Eds.). Cultura organizacional e cultura brasileira (pp. 55-69). São Paulo: Atlas.

Souza, E. M., \& Costa, A. M. (2013). Usos e significados do conhecimento histórico em estudos organizacionais: uma (re)leitura do taylorismo sob a perspectiva do poder disciplinar. Cadernos EBAPE. $B R, 11(1), 1-15$.

Salin, D. (2008). The prevention of workplace bullying as a question of human resource management: measures adopted and underlying organizational factors. Scandinavian Journal of Management, 24(3), 221-231.

Soylu. S., \& Sheehy-Skeffington. J. (2015). Asymmetric intergroup bullying: The enactment and maintenance of societal inequality at work. Human Relations, 68(7), 1099-1129.

Vasconcelos, Y. L. (2015). Assédio moral nos ambientes corporativos. Cadernos EBAPE.BR, 13(4), 821851.

Yin, R. K. (2005). Estudo de caso: planejamento e métodos. 2. Ed. Porto Alegre: Bookman.

Zanin, F., Künzle, L. A., Barreto, M., \& Heloani, R. (2015). Modificações neoliberais na universidade pública brasileira: cenário propício para o assédio moral no trabalho. In: Gediel, J. A. P., Silva, E. F., Zanin, F., \& Mello L. E. (Orgs.). Estado, poder e assédio: relações de trabalho na administração pública (pp. 185-204). Curitiba: Kairós Edições.

Zapf, D. \& Einarsen, S. (2003). Individual antecedents of bullying: victims and perpetrators. In Einarsen, S., Hoel, H. Zapf, D. \& Cooper, C. L. (Eds.). Bullying and emotional abuse in the workplace: International perspectives in research and practice (pp. 165-184). London: Taylor \& Francis.

Submetido em: $30 / 05 / 2018$

Aprovado em: 02/09/2019 